\title{
La conservación de los materiales pétreos en la Fuente de Cibeles, Madrid (España)
}

\section{Conservation of the stone in Cibeles Fountain, Madrid (Spain)}

\author{
M.C. LÓPEZ DE AZCONA,R. FORT GONZÁLEZ, F. MINGARRO MARTÍN
} Instituto de Geología Económica (CSIC-UCM). Facultad de Ciencias Geológicas

\section{RESUMEN}

El agua de la Fuente de Cibeles funciona en un circuito cerrado, con cambio cada seis meses del agua. Al final de un periodo el agua tiende a incrementar su contenido en bicarbonatos, sulfatos, calcio y magnesio, con una ligero aumento de su acidez, con respecto al agua original. Esta acidez, favorecida por la acción de la contaminación atmosférica, genera procesos de disolución en los mármoles con los que está esculpida la parte escultórica de la Fuente. Son los mármoles calciticos, procedentes de las canteras de Carrara (Italia), de los amorcillos, los que tienen un mayor proceso de disolución, mientras que los mármoles dolomíticos, con los que está esculpido el conjunto escultórico principal, presentan menos procesos de disolución. Los elementos en disolución precipitan en zonas determinadas del conjunto escultórico y en elementos de la Fuente, dando la formación de costras e incrustaciones.

Para evitar la degradación de los materiales de la Fuente de Cibeles es necesario controlar periódicamente la composición de su agua para estabilizarla a un pH entorno a 7,8. Igualmente es necesario agregar compuestos quimicos específicos para evitar la proliferación bacteriana $y$ de algas, mejorando la calidad del agua.

\section{SUMMARY}

The water in Cibeles Fountain flows in a closed circuit and is replaced every 6 months. After this period of time, an increase in bicarbonate, sulfate, calcium and magnesium contents is registered in the water, as well as a slight increase in its acidity. This acidity, favored by atmospheric pollution, is the main cause for the process of dissolution that marble used in the ornamental sections of the fountain undergoes. Calcite-based marble, from the Carrara quarries in Italy, of the cherubs suffers the most acute dissolution processes, while dolomite-based marble, used for the main sculpture body is less affected by these processes. Dissolved materials fall on certain sections of the sculpture and of the fountain forming dirt crusts and inlaid soiling.

In order to prevent decay of the fountain building materials, periodical control of water composition is necessary, with a view to stabilizing water $\mathrm{pH}$ level at around 7.8. It is likewise necessary to add chemicals that prevent bacteria and algae proliferation, thus improving water quality.
PALABRAS CLAVE: mármol, petrofísica, hidroquímica, conservación patrimonio.

\section{INTRODUCCIÓN}

Resulta gratificante el contemplar, dentro del medio urbano, una plaza o jardín adornado con alguna fuente, pero su conservación es dificil y pronto pueden transformarse en conjuntos invadidos por plantas, costras y suciedad que enmascaran el ornamento y anulan el efecto perseguido.
KEYWORDS: marble, petrophysic, hydrochemical, conservation, monumental heritage.

\section{INTRODUCTION}

Fountains in gardens and squares are a pleasure to look at in the midst of the urban environment. However, the correct preservation of these monuments from decay can often prove to be very problematic. They can soon be covered in vegetation, dirt crusts and dirt that obliterate their beauty, canceling out the ornamental effect. 
Uno de los factores fundamentales en la conservación de las fuentes es el conocimiento de la composición química del agua, que puede regular la disolución y transformación de los minerales del material pétreo de la fuente, e incluso favorecer la precipitación de nuevas fases minerales sobre su superficie. Además hay que tener presente que la composición del agua determina las propiedades físicas de la misma.

El mantenimiento del agua en una fuente es similar al mantenimiento del agua de una piscina, donde se necesita un tratamiento específico para su conservación, puesto que en caso contrario el agua se deteriora y es necesario vaciarla con el consiguiente desperdicio del agua, siendo éste un bien escaso.

Las fuentes son monumentos escultóricos dinámicos que pierden su carácter cuando lo hace el material de construcción, el agua y su movimiento, por eso deben estar siempre funcionando con agua limpia, para que no se deteriore el material constructivo.

\section{OBJETIVOS}

El problema de la conservación y restauración de las fuentes es complejo, pues hay que conjugar muchos factores: el conocimiento estricto de las características petrográficas, petrofísicas y petroquímicas del material, la composición química del agua y su temperatura, siempre cambiante, ya sea en circuito cerrado o abierto, su hidromecánica peculiar, y el medio ambiente físico y químico que la rodea.

El Objetivo del este trabajo es establecer las características del material pétreo con que está construido la Fuente de Cibeles (Madrid), para deducir su estado de degradación y los efectos de la circulación continua del agua por la superficie de sus materiales. El objetivo final es deducir la mejor forma de conservarla con una mínima intervención.

\section{BREVE HISTORIA DE LA FUENTE DE CIBELES}

El Rey Carlos III encarga al arquitecto Ventura Rodríguez y al ingeniero José Hermosilla la remodelación de la alameda del Prado de San Jerónimo. En 1777 se realiza el proyecto con idea de un gran hipódromo griego y para su ornamentación erigen tres monumentos de la mitología griega: Neptuno, el dios de los océanos en un extremo, Apolo dios de la luz, la gracia y la belleza en el centro, y en el otro extremo la diosa Cibeles que procedente de Frigia (Anatolia) simboliza la fertilidad de la tierra.
One of the fundamental factors is the chemical composition of water, that can be at the heart of the dissolution and transformation of the minerals found in the stone of the fountain and can also induce the precipitation of new mineral phases on the surface. It should also be taken into consideration that the water composition bears directly on the its physical properties.

In general terms water maintenance for a fountain is similar to that for a swimming pool where specific measures are to be adopted in order to avoid water decay. This water decay would entail a complete renewal with the ensuing waste of such a scant resource.

Fountains are dynamic sculptures that lose their character when their materials, water and movement are in decay. Thus, they should always run on clean water to prevent this decay of materials.

\section{AIMS}

Conservation and restoration of fountains is very complex as there are many factors to be taken into account: in-depth knowledge of the petrographic, petrophysical and petrochemical characteristics of the materials; temperature and chemical composition of water used (which are in constant change both in a closed or in an open circuit); its particular hydromechanics; and the physical and chemical environment surrounding it.

The objective of the this work is to establish the characteristics of the stony material with which it is built the Cibeles Fountain (Madrid), to deduce its degradation state and effects the continuous circulation of the water for the surface of its materials. The final objective is to deduce the best form from conserving it with a minimum intervention.

\section{SHORT HISTORY OF THE CIBELES FOUNTAIN}

King Charles III commissioned architect Ventura Rodriguez and engineer José Hermosilla to redesign the tree-lined avenue located in Prado de San Jerónimo. A grand Greek-style hippodrome is projected. Work begins in 1777 with the sculpting of three ornamental monuments portraying figures from Greek mythology: Neptune, God of the ocean (to be located at one end of the avenue); Apollo, God of light, grace and beauty (in the central part); and Goddess Cibeles from Frigia (Anatolia) that symbolizes fertility of the soil (at the other end). 
Francisco Gutiérrez esculpe la diosa Cibeles con el trono y Roberto Michel los Leones. En 1782 se instala un pilón redondo mirando hacia Atocha o mejor hacia Neptuno, colocándola en el Palacio de Buenavista. En 1791 Juan de Villanueva añade el símbolo del Madrid de entonces: un oso y un dragón. Este elemento ornamental apareció en Puerta Cerrada (1), en la antigua muralla de Madrid, derribada en 1569.

Todos los materiales de la escultura corresponden a mármoles dolomíticos de Montesclaros (Toledo) (2), hasta que en 1894 el arquitecto López Sallavery sustituye el oso y dragón por dos amorcillos con un tritón y ánfora que Trilles y Pereira esculpen en mármol de Carrara. La posición actual de la Fuente se adquiere en 1895 , en que se traslada al centro de la Plaza y se orienta mirando a la Puerta del Sol (3).

Después de las restauraciones de 1931 y 1936, en el 1968 se efectúa otra, se vuelve a restaurar colocando un nuevo pilón y la iluminación actual. En el año 1984 se restaura otra vez, al sacar un molde para mandar una replica a Méjico. En los últimos años ha sufrido actos vandálicos, que ha necesitado intervenciones de restauraciones puntuales.

\section{METODOLOGÍA}

La caracterización petrológica de los materiales pétreos de la fuente se realizó por medio de un microscopio ZEISS de luz polarizada y la mineralogía se determinó por medio de la difracción de la Rayos (XRD) (PHILIPS PW-1752, ánodo del Tubo Cu). Los análisis químicos de las rocas se analizaron por medio de la técnica de espectrometría de emisión atómica con acoplamiento inductivo de plasma (ICP-AES).

Los análisis químicos del agua de la fuente y del Canal de Isabel II se realizaron por medio de cromatografia iónica (Dionex DX-500).

En la caracterización petrofísica de los materiales se incluyó su comportamiento hídrico: saturación de agua al vacio, absorción de agua libre, desorción de agua y permeabilidad al vapor de agua. Los ensayos del comportamiento hídrico se realizaron siguiendo las recomendaciones de RILEM (4) y ICR-CNR NORMAL(5).

La porosidad y distribución de tamaño de poro se ha determinado por medio de un porosímetro de mercurio (porosimeter de Autoscan, Quantachrome). El volumen de mercurio intruido, para cada intervalo de presión, permite determinar el volumen de poros abiertos o circulantes. Después de la realización de la intrusión y posterior extrusión, dentro del sistema poroso queda
Francisco Gutiérrez was responsible for the sculpture portraying Goddess Cibeles on her throne while Roberto Michel was in charge of sculpting the lions. In 1782 a round basin was set up in Palacio de Buenavista looking towards the Neptune monument. In 1791 Juan de Villanueva places on this basin a sculpture portraying what was at the time the symbol of Madrid: a bear and a dragon. This ornament was found in Puerta Cerrada (1), in the old wall that surrounded Madrid, which was demolished in 1569.

The sculpture was done entirely on dolomite marble from Montesclaros (Toledo) (2). In 1894 architect López Sallavery replaces the bear and dragon with two cherubs with a triton and an amphora. These figures were sculpted on Carrara marble by Trilles and Pereira. The fountain changes its position in 1895 , when it is moved to the center of the square and turned to look towards Puerta del Sol (3).

After the earlier restorations carried out in 1931 and 1936, the fountain underwent a further one in 1968, where a new basin and the lighting presently used were installed. Its last restoration is carried out in 1984, when a cast model is made in order to send a copy to Méjico. Isolated cases of vandalism have made specific restoration necessary.

\section{METHODOLOGY}

A petrological characterization of the stone was carried out: its petrological and mineralogical characteristics were determined by means of X-Ray diffraction (XRD) (PHILIPS PW-1752, Tube anode Cu), polarizing light microscopy (ZEISS-West Germany), chemical analyses were also carried out using atomic emission spectrometry with inductive-coupling-plasma (ICPAES).

The chemical analyses of the water of the fountain and of Isabel's II Channel they were carried out by means of ionic cromatography (Dionex DX-500).

The petrophysical characterization carried out included the following hydric behavior: water absorption, water saturation level, water desorption, water vapour permeability. Tests were carried out following the RILEM recommendations (4) and the ICR-CNR NORMAL (5).

Porosity and pore size distribution were determined by means of a mercury intrusion porosimeter (Autoscan porosimeter, Quantachrome). The volume of intruded mercury for each pressure step allows determination of the total open pore volume. After completion of intrusion and extrusion some mercury always remains in the pores. The volume of this trapped mercury represents the volume 
retenido algo de mercurio, que corresponde al volumen de poros atrapados y que están relacionados con la existencia de poros en "cuello de botella" (6 y 7).

\section{CARACTERÍSTICAS PETROLÓGICAS DE LA FUENTE}

Los materiales de construcción para esculpir la Diosa con su carro y los leones, así como el pedestal de rocalla que la soporta. són mármoles dolomíticos procedentes de las canteras de Montesclaros (Toledo). Este material es un mármol metamórfico dolomítico muy puro, que forma un mosaico granoblástico equigranular muy grueso para el carro y Diosa (Figura 1), mientras que el de los leones es más heterogranular y alotriomorfo de grano más fino; sólo en algún bloque de la rocalla, se presenta un mármol calco-dolomítico de grano muy fino, con más impurezas de tipo pirita y feldespato potásico y que tal vez proceda de la restauración de 1968.

Otro material carbonático, lo forman los mármoles calcíticos con los que se esculpieron los amorcillos. Este material procedente de Carrara (Italia), forma un mosaico de calcita granoblástica equigranular de tamaño medio de $0,3 \mathrm{~mm}$, que sólo presenta esporádicamente algunas impurezas de grafito y feldespatos alterados (Figura 2).

Finalmente, el granito adamellítico de Valdemorillo (Madrid) es con el que construyeron los pilones. Se trata de una adamellita biotítica equigranular, en la que sus componentes principales son el cuarzo, el feldespato potásico tipo ortosa con cristales alotriomorfos, junto con microclina pertítica; las plagioclasas son alcalinas con inclusiones de biotita y mucha albita zonada con el núcleo de andesita que pasa a oligoclasa y albita. La biotita se presenta en cristales tubulares y a veces como agregados policristalinos.

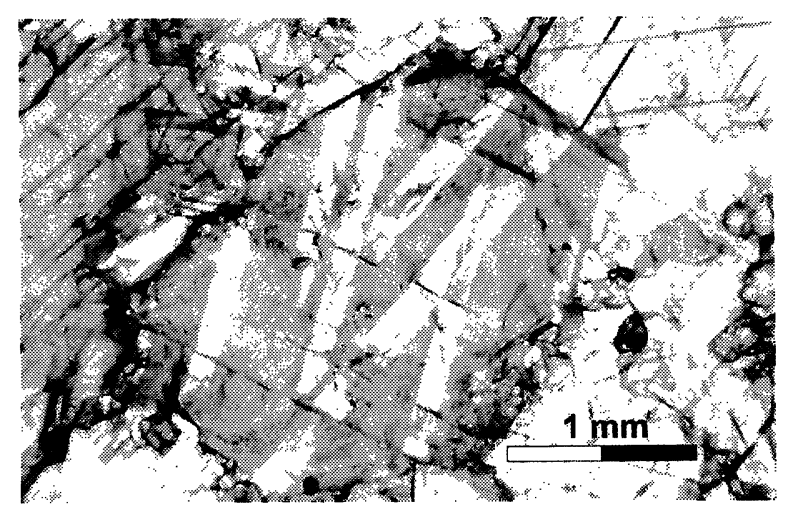

Figura 1.- Fotomicrografia del mármol de Montesclaros (Diosa de la Fuente).

Figure 1.- Photomicrograph of the marble from the Montesclaros (Sculpt the Godess). of large pores which are conected with a narrow throat, the "ink-bottle" pore system (6 and 7).

\section{PETROLOGICAL CHARACTERISTICS OF THE FOUNTAIN}

Dolomite marble from the Montesclaros quarries (Toledo) was used to sculpt the Goddess, her chariot and the lions. The stone chippings that forms the pedestal is also dolomite marble. This stone is a very pure metamorphic dolomite forming a thick granoblastic, equigranular mosaic for the chariot and the Goddess (Figure 1). That of the lions is finer grained and more markedly heterogranular and allotriomorphic. It is only in the occasional stone chippings that a finer-grained chalcodolomite with pirite and potassium feldspar impurities is found. This type of stone may have been added in the 1968 restoration.

Another carbonaceous material is the calcite marble that the cherubs were sculpted. This material, original from Carrara (Italy), forms a granoblastic, equigranular calcite strip of $0.3 \mathrm{~mm}$ average size, with some occasional graphite impurities and some feldspar (Figure 2).

Adamellite granite from Valdemorillo (Madrid) was used for the basins. This type of granite is an equigranular biotite adamellite, basically made up of quarz, potassium feldspar (ortose variety) with allotriomorphic crystals and perthitic microcline. Plagioclastic materials found are alkaline with some biotite and a fair amount of albite in the andesine nucleus that turns into oligoclase and albite. The biotite appears in the shape of tubular crystals and sometimes policrystalline clusters.

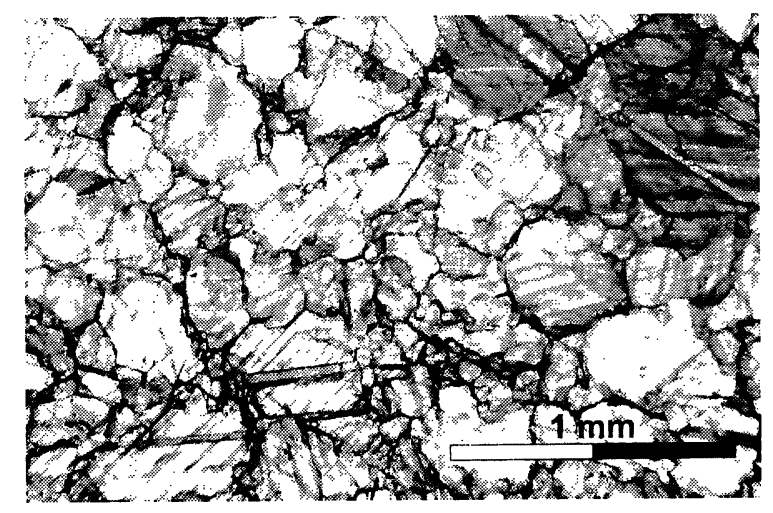

Figura 2.- Fotomicrografia del mármol de Carrara (amorcillos).

Figure 2.- Photomicrograph of the marble from the Carrara (sculpt cherubs). 
TABLA $1 / T A B L E 1$

Análisis químicos de los materiales y sus canteras

Chemical analysis of materials and quarries

\begin{tabular}{|c|c|c|c|c|c|c|}
\hline & $\mathbf{A}$ & B & $\overline{\bar{C}}$ & $\overline{\text { D }}$ & $\bar{E}$ & F \\
\hline $\mathrm{SiO}_{2}$ & 0,12 & 0,52 & 0,12 & 1,08 & 68,91 & 68,97 \\
\hline $\mathbf{A l}_{2} \mathrm{O}_{3}$ & 0,03 & 0,25 & 0,04 & 0,03 & 14,86 & 15,17 \\
\hline $\mathrm{Fe}_{2} \mathrm{O}_{3}$ & 0,20 & 0,18 & Traza & 0,16 & 3,61 & 3,26 \\
\hline MnO & 0,05 & 0,03 & Traza & Traza & 0,05 & 0,06 \\
\hline MgO & 21,62 & 21,99 & 0,8 & 0,55 & 1,16 & 1,19 \\
\hline $\mathrm{CaO}$ & 31,03 & 30,77 & 55,50 & 54,28 & 2,41 & 2,47 \\
\hline $\mathrm{Na}_{2} \mathrm{O}$ & Traza & Traza & Traza & 0,03 & 3,03 & 3,21 \\
\hline $\mathrm{K}_{2} \mathrm{O}$ & Traza & Traza & Traza & 0,02 & 3,93 & 4,07 \\
\hline $\mathrm{TiO}_{2}$ & Traza & Traza & Traza & Traza & 0,48 & 0,55 \\
\hline $\mathrm{P}_{2} \mathrm{O}_{5}$ & Traza & 0,01 & 0,02 & Traza & 0,16 & 0,13 \\
\hline PF & 46,67 & 45,48 & 43,43 & 45,75 & 0,98 & 1,11 \\
\hline
\end{tabular}

A.- Mármol dolomítico de Montesclaros

B.- Mármol dolomítico del Monumento

(Dolomite marble from Montesclaros)

C. - Mármol calcítico del Monumento

(Dolomite marble from the fountain)

D. - Mármol calcítico de Carrara

(Calcite marble from the fountain

E.- Adamellita biotítica del Monumento

(Calcite marble from Carrara)

F. - Adamellita biotítica de Valdemorillo

(Biotite adamellite from the fountain)

(Biotite adamellite from Valdemorillo[8]

La Tabla I presenta los análisis químicos medios de estos materiales, tanto del monumento como de las canteras originales. Los mármoles dolomíticos del conjunto escultórico principal de la Fuente están constituidos, atendiendo a estos análisis petroquímicos, por un $98,9 \%$ de dolomita, mientras que los mármoles calcíticos tienen un $99 \%$ de calcita, demostrando la pureza composicional de los materiales.

Un dato importante para comprender la alterabilidad de los materiales es el conocimiento del comportamiento hídrico de los mismos, cuyos principales valores se expresan en la Tabla II. Hay que destacar, para las rocas marmóreas, cómo las de naturaleza calcítica absorben ligeramente más cantidad de agua que las dolomíticas. Esta absorción se realiza de una forma más rápida, lo que se pone de manifiesto al contemplar los grados de sorción-desorción, que determinan que en los mármoles calcíticos, el tamaño de los poros es mayor $y$ pueden perder todo el agua, tomada en muy poco tiempo, por lo que su durabilidad es menor, por procesos de humedad-sequedad y por tener una solubilidad más alta, favoreciendo los procesos de disolución.

La porosidad en los mármoles calcíticos es mayor que la de los mármoles dolomíticos, en un 45,3\% (Tabla III). La porosidad circulante o libre es un 28,6 menor, por eso la permeabilidad al agua resulta ser ligeramente superior, pero siempre, insignificante para
Table I contain the average chemical contents of these materials taken from samples from both the monument and the quarries. According to the petrochemical analysis, the dolomite marble of the fountain is composed of $98.9 \%$ dolomite, while calcite marble contains $99 \%$ calcite, which demonstrates the compositional purity of the materials.

An important factor to bear in mind when studying the alterability of materials is their hydric behavior. Main values are displayed in Table II. When dealing with marble, it must be taken into consideration that calcite marble absorbs slightly more water than dolomite. This activity is process is carried out faster, fact that is reflected in the sorption-desorption values. According to this data, calcite marble has wider pores and can lose all the water that has been so quickly absorbed. Durability for this type of stone is thus lower, for processes of humidity-dryness and to have a higher solubility, favoring the break-up processes.

Calcite marble porosity is $45.3 \%$ higher than that of dolomites (Table III). Circulatory or free porosity is 28.6\%lower; thus, its water permeability values are slightly higher. However permeability levels for both materials are too low to be of significance. Porometric 
TABLA 2/TABLE 2

Comportamiento hídrico de materiales

Hydric behaviour of materials

\begin{tabular}{|l|c|c||c|c||}
\cline { 2 - 5 } \multicolumn{1}{|c|}{} & \multicolumn{2}{c||}{ Mármol / Marble } & \multicolumn{2}{c||}{ Granito/Granite } \\
\cline { 2 - 5 } \multicolumn{1}{|c|}{} & $\begin{array}{c}\text { Dolomítico } \\
\text { Dolomite }\end{array}$ & $\begin{array}{c}\text { Calcítico } \\
\text { Calcite }\end{array}$ & $\begin{array}{c}\text { Carro } \\
\text { Chariot }\end{array}$ & $\begin{array}{c}\text { Vaso } \\
\text { Basin }\end{array}$ \\
\hline \begin{tabular}{|l|c|c||} 
Porosidad accesible al agua \% \\
Water Porosity \%
\end{tabular} & 0,34 & 0,52 & 2,83 & 1,50 \\
\hline $\begin{array}{l}\text { Saturación \% } \\
\text { Saturation \% }\end{array}$ & 0,12 & 0,19 & 1,08 & 0,56 \\
\hline $\begin{array}{l}\text { Sorción 24 h \% } \\
\text { Sorption 24 h \% }\end{array}$ & 0,09 & 0,18 & 0,64 & 0,36 \\
\hline $\begin{array}{l}\text { Sorción grado } \\
\text { \% Sorption degree \% }\end{array}$ & 75,0 & 94,7 & 59,2 & 64,3 \\
\hline $\begin{array}{l}\text { Desorción 24 h \% } \\
\text { Desorption 24 h \% }\end{array}$ & 0,12 & 0,19 & 0,64 & 0,32 \\
\hline $\begin{array}{l}\text { Desorción grado \% } \\
\text { Desorption degree \% }\end{array}$ & 99,2 & 100 & 59,3 & 57,1 \\
\hline $\begin{array}{l}\text { Permeabilidad al Agua (\%) } \\
\text { Water permeability (\%) }\end{array}$ & 0,15 & 0,16 & 0,93 & 0,69 \\
\hline
\end{tabular}

$\%$ en peso

$\%$ in weight

TABLA 3/TABLE 3

Porosimetría por intrusión de mercurio

Mercury porosimeter data

\begin{tabular}{|l||c|c||c|c||}
\cline { 2 - 5 } \multicolumn{1}{c|}{} & \multicolumn{2}{c|}{ Mármol/Marble } & \multicolumn{2}{c||}{ Granito/Granite } \\
\cline { 2 - 5 } \multicolumn{1}{c|}{} & $\begin{array}{c}\text { Dolomítico } \\
\text { Dolomite }\end{array}$ & $\begin{array}{c}\text { Calcítico } \\
\text { Calcite }\end{array}$ & $\begin{array}{c}\text { Carro } \\
\text { Chariot }\end{array}$ & $\begin{array}{c}\text { Vaso } \\
\text { Basin }\end{array}$ \\
\hline $\begin{array}{l}\text { Porosidad accesible al Hg (\%) } \\
\text { Hg porosity (\%) }\end{array}$ & 1,06 & 1,54 & 2,47 & 2,53 \\
\hline $\begin{array}{l}\text { Porosidad libre (\%) } \\
\text { Free porosity (\%) }\end{array}$ & 42 & 30 & 33 & 46 \\
\hline $\begin{array}{l}\text { Porosidad atrapada (\%) } \\
\text { Trapped porosity (\%) }\end{array}$ & 58 & 70 & 67 & 54 \\
\hline
\end{tabular}

$\%$ en volumen

$\%$ in volume

ambos mármoles. La distribución porométrica de estos materiales (Figura 3), muestra que no tienen poros en el intervalo comprendido entre 1 y $0,2 \mu \mathrm{m}$,

consiguientemente, se originan "cuellos de botella", y la circulación de agua es imposible, por lo que ésta se reduce en un $55 \%$, para los mármoles dolomíticos.

Respecto a los granitos adamelliticos de la gran losa que soporta el carro de la Diosa y el del segundo pilón, colocados con una diferencia de casi dos siglos, seguramente proceden de la misma cantera de Valdemorillo, pero se diferencia petrofisicamente. En general todos los valores de la adamellita del carro son superiores a los del vaso o pilón, lo que determina su distribution of these materials (Figure 3), shows that they have no pores in the 1-0.2 $\mu \mathrm{m}$ interval, which generates trapped pores making water circulation impossible as it is cut down by $55 \%$, for dolomites marbles

The adamellite granite of the large plank of stone supporting the chariot and that of the second basin (one set up almost two centuries later than the other) were probably extracted from the same quarries (Valdemorillo) but have petrophysical differences. In general terms, values for the adamellite stone in the chariot are higher than 
mayor permeabilidad y alterabilidad, con un mayor grado de arenización; sólo el grado de sorción del granito del pilón es superior al del carro, lo que indica que los granitos de éste tienen los poros más finos, tomando más agua de saturación $(1,08 \%)$, pero evaporándola más lentamente.

En cuanto a los datos porométricos (Tabla III), la porosidad total es de $2,4 \%$, siendo mayor en el vaso que en el soporte del carro, pero la porosidad libre le supera en un 39,3\%. No obstante, y según el agua de saturación, resulta que el agua que puede circular por el granito del carro es superior a la del vaso, con lo que los de aquél son más alterables. En el carro la arenización es superior a la del vaso. Todo esto se pone más de manifiesto al observar los histogramas porosimétricos (Figura 4), en que incluso para el vaso existe un "cuello de botella" en el intervalo 0,6-0,7 $\mu \mathrm{m}$. those for the basin stone, making it more permeable and alterable with higher erosion levels. Only the values for sorption are higher for the basin, which indicates that the granite used for sculpting the chariot has smaller pores. This favours the uptake of saturation water (1,08\%), but slows down the evaporation process.

As to porometrics (Table III), total porosity is $2.4 \%$, with higher values for the basin than for the chariot. Conversely, free porosity is $39.3 \%$ higher in the chariot than in the basin. Nonetheless, according to the water saturation level, the amount of water that can flow in the chariot granite is higher than that of the basin, therefore the former is more alterable. Grain disgregation levels are higher for the chariot. All this becomes apparent studying the porometric distribution (Figure 4), according to which there is even a trapped porosity for interval 0.6-0.7 $\mu \mathrm{m}$ in the basin.

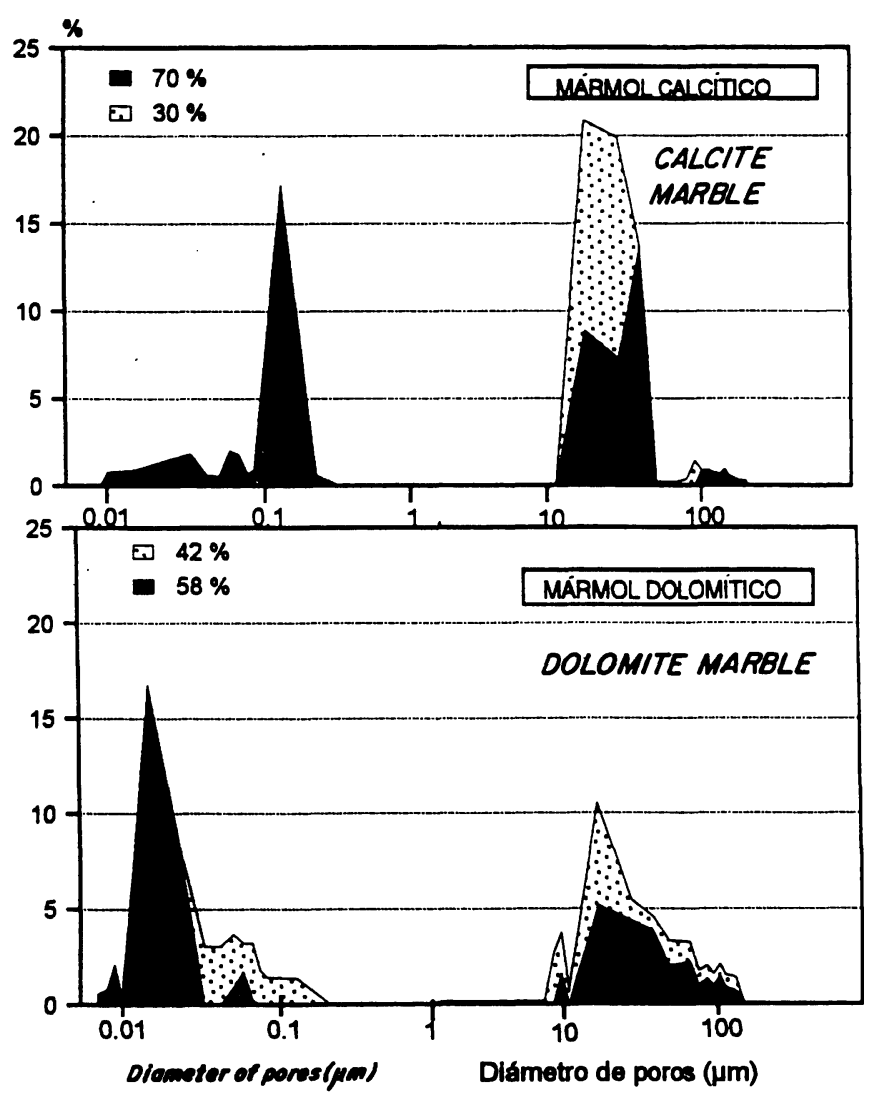

Figura 3.- Distribución de los tamaños de poros de los mármoles de la Fuente de Cibeles. Negro: porosidad atrapada. Puntos: porosidad libre o circulante.

Figure 3.- Pore size distribution of Fuente Cibeles marble. Black: trapped porasity. Dotted area: free/circulatory porosity.

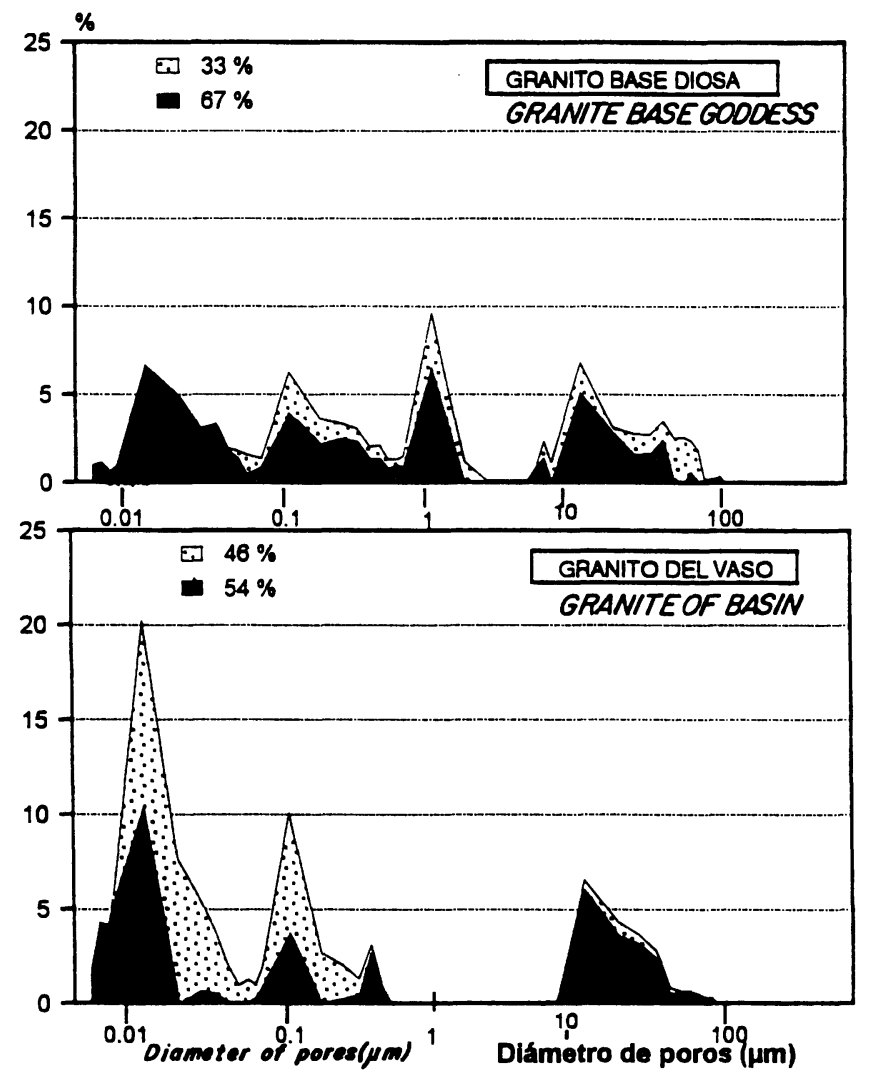

Figura 4.- Distribución de los tamaños de poros de los granitoides de la Fuente de Cibeles. Negro: porosidad atrapada. Puntos: porosidad libre o circulante.

Figure 4.- Pore size distribution of Fuente Cibeles granite. Black: trapped porosity. Dotted area: free/circulatory porosity. 


\section{EL AGUA DE LA FUENTE}

La fuente de Cibeles, con tres pilones desde hace 31 años, tiene una capacidad de $279 \mathrm{~m}^{3}$ de agua, que en circuito cerrado abastece, mediante bombeo, los surtidores del primer pilón, rebosando luego a los otros. El circuito está conectado a un filtro de arena actualmente en desuso. La Fuente funciona diariamente desde las 10 hasta las 23 horas. El agua se renueva aproximadamente cada 6 meses, después de circular unas 2.400 horas.

Al final de un período, en el mes de septiembre, se tomaron muestras del agua de la Fuente y del Canal de Isabel II de la que se abastece. Los resultados obtenidos del análisis químico se muestran en la Tabla IV. En el agua de la Fuente destacan el incremento de cloruros, sulfatos y bicarbonatos, con respecto la composición del agua del Canal, sólo explicable por la disolución de contaminantes atmosféricos, especialmente durante el funcionamiento de los surtidores. $\mathrm{El}$ incremento de estos compuestos justifica el aumento de la acidez del agua, aunque no tan fuerte como cabría esperar, por verse neutralizada por la disolución de dolomita y calcita del Monumento, que incorpora cationes $(\mathrm{Ca}$ y $\mathrm{Mg}$ ). La presencia de estos elementos también favorecen la gran proliferación de microorganismos y algas, lo que, a su vez, pone de manifiesto la desaparición de nitratos del agua del Canal y del

\section{THE WATER IN THE FOUNTAIN}

Cibeles fountain has had three basins for 31 years. Its water capacity is $279 \mathrm{~m}^{3}$. Water is pumped in a closed circuit to the first basin until it fills up and overflows onto the others. The circuit is linked to a sand filter, which is currently not being used. The fountain is activated daily from 10 a. m. to 23 p.m. On average, water is renewed every six months after flowing for some 2.400 hours.

In september, after one of these six-month periods, water samples were taken from the fountain and from the water supplier: Canal de Isabel II. Results obtained of the chemical analysis are summarized in Table IV. A significant increase of chlorides, sulfates and bicarbonates was recorded in the fountain water. This increase can only be due to the dissolution of pollutants especially while the pumps are in use. This increase in turn explains the increase in water acidity which is, nonetheless, less pronounced than expected as it is neutralized by the dissolution of dolomite and calcite, materials that contain cations ( $\mathrm{Ca}$ and $\mathrm{Mg}$ ). The presence of these elements also benefits the proliferation of microorganisms and algae, which accounts for the disappearance of nitrates that were present in the

TABLA 4/TABLE 4

Análisis del agua de la Fuente Analysis of Fountain water

\begin{tabular}{|c|c|c|c|c|}
\hline & & $\begin{array}{c}\text { Canal } \\
\text { Source }\end{array}$ & $\begin{array}{c}\text { Fuente } \\
\text { Fountain }\end{array}$ & $\% \Delta$ \\
\hline Sodio & (Sodium) & 7 & 7 & $\pm 0,00$ \\
\hline Potasio & (Potassium) & 1 & 1 & $\pm 0,00$ \\
\hline Amonio & (Ammonium) & 0 & 0 & $\pm 0,00$ \\
\hline Magnesio & (Magnesium) & 3 & 6 & $+100,00$ \\
\hline Calcio & (Calcium) & 20 & 30 & $+50,00$ \\
\hline Cloruros & (Chlorides) & 7 & 10 & $+42,86$ \\
\hline Sulfatos & (Sulfates) & 38 & 42 & $+10,53$ \\
\hline Bicarbonatos & (Bicarbonates) & 40 & 73 & $+82,50$ \\
\hline Carbonatos & (Carbonates) & 0 & 0 & $\pm 0,00$ \\
\hline Nitratos & (Nitrates) & 2 & 0 & $-100,00$ \\
\hline Nitritos & (Nitrites) & 0 & 0 & $\pm 0,00$ \\
\hline Fosfatos & (Fosfates) & $<0,05$ & $<0,05$ & $\pm 0,00$ \\
\hline Sílice & (Silice) & 6,6 & 0 & $-100,00$ \\
\hline pH & & 7,8 & 7,2 & $-7,69$ \\
\hline Conductividad & (Conductivity) & 184 & 242 & $+31,52$ \\
\hline Demanda de 0 & $\left(\mathrm{O}_{2}\right.$ demand $)$ & 0,6 & 0,5 & $-16,67$ \\
\hline
\end{tabular}

Datos en $\mathrm{mg} \cdot \mathrm{l}^{-1}$ Conductividad en $\mu \mathrm{S} \cdot \mathrm{cm}^{-1}$

Data expressed in $\mathrm{mg} \cdot \mathrm{l}^{-1} /$ conductivity in $\mu \mathrm{S} \cdot \mathrm{cm}^{-1}$ 
aportado por la contaminación ambiental del entorno. Esto hace que disminuya la demanda de oxígeno, ya que los surtidores favorecen la incorporación de éste al agua, si no la demanda de oxígeno sería mucho más alta.

Hay que tener en cuenta que la composición del agua varía continuamente, no sólo por su sustitución semestral, sino por la variación de la contaminación atmosférica. Los análisis presentados corresponden al semestre menos contaminado, con mayor insolación y temperatura, por esto convendría hacer análisis mensuales durante un año.

El efecto surtidor, conlleva la disolución de contaminantes solubles, pero también el arrastre de partículas en suspensión, que favorecen la proliferación vegetal a la vez que protege a la Diosa de su enmugrecimiento, que siempre está mas limpia que los leones.

Las principales huellas de disolución se presentan en los amorcillos y, muy en segundo término, en la rocalla, que soporta al conjunto escultórico. Hay que tener en cuenta que el Monumento, propiamente dicho, está tratado con productos sílico-orgánicos y también que con estos valores de acidez, la dolomita es poco soluble, por lo que el aumento de magnesio debe atribuirse no sólo a la hidrólisis de la adamellita sino posiblemente también a los morteros que unen la rocalla a la diversa composición de estas dolomías y, en parte también, a los morteros que unen los sillares de los pilones, con lo que también se aportaría calcio y así se explica la presencia de costras cálcicas sobre las ademallitas.

Las precipitaciones o formación de costras son de dos tipos: las de carbonato cálcico y las de sulfato cálcico. Las primeras, se encuentran principalmente sobre los amorcillos, aunque también aparecen sobre las adamellitas, pero en contacto y a expensas de los rellenos de llagas. Esto pone de manifiesto la importancia de la concentración de dióxido carbónico en el aire, las fluctuaciones del $\mathrm{pH}$ y las variaciones térmicas y de presión, todo lo cual conlleva a épocas en donde predominan las disoluciones y a otras donde lo que abundan son las precipitaciones.

Los precipitados de sulfato cálcico se consideran biogénicos, en que algas, bacterias y hongos heterótrofos definen un ecosistema específico, seguramente poiquilotermio, donde los condicionantes térmicos vitales proceden del exterior, en nuestro caso cuando se encienden los focos de iluminación de la Fuente. Ésta es la razón, por lo que dichas costras se presentan en la superficie water originally supplied by Canal de Isabel II and also shed by pollution. Oxygen demand is lower as the pumps aid its influx to the system.

It should be taken into account that water composition varies continuously, not only due to its being replaced periodically, but also to the variability of pollution values. Values recorded correspond to analysis carried out during the period with least pollution, highest sun exposure and temperature. It would, therefore, be advisable to carry out monthly tests over a whole year.

The pumping system induces the dissolution of soluble pollutants, but also the intake of suspension particles that benefits the growth of vegetation while protecting the statue of the Goddess from soiling. This sculpture is always cleaner than those portraying the lions are.

The cherubs display the most significant signs of dissolution and also, but less acutely in the stone chippings, at the base of the group of sculptures. It must be taken into consideration that a siliceousorganic treatment has been applied on the Monument as such and that, given the acidity values, dolomite is not very soluble. Thus, the increase of magnesium should not only be attributed to the hidrolysis of the adamellita but possibly also to the mortar that holds the stone chippings together, to the varied composition of the dolomite and, partly, to the mortars that join the ashlars of the basins, with what calcium would also be contributed and the presence of calcic scabs is explained this way on the ademallitas.

Precipitation and crust formation belong to two categories: calcic carbonate and calcic sulfate. The first two are to be found mainly on the cherubs, although they can also be found on the on the surface of the adamellite due to the joint filling. This highlights the important effect of carbon dioxide in the air, of $p H$ variations and pressure and thermal variations, which cause for dissolution precipitations prone periods to alternate.

Calcium sulfate precipitations are considered to be biogenic, as algae, bacteria and heterotrofous fungi define a specific ecosystem, more than likely poikilothermic, where life thermal conditions are dictated by the outside, in this case when the lighting around the fountain is turned on. This is the reason why crusts can be found on the lighting appliances. 
de los focos. Biocatalizadores enzimáticos del grupo de las desmolasas descomponen los proteídos, liberando iones sulfato y puntualmente aumenta su concentración y provoca la precipitación puntual del sulfato cálcico.

\section{CONCLUSIONES}

El grupo escultórico principál de la Fuente está esculpido con mármol dolomítico procedentes de las canteras de Montesclaro (Toledo, España). Los amorcillos colocados en 1864 se esculpieron con mármol calcítico de Carrara (Italia). Los vasos de la fuente son de adamellitas biotíticas procedente de canteras de Valdemorillo (Madrid, España). Estos mármoles calcíticos de los amorcillos son los que presentan un peor estado de conservación, con procesos de disolución por donde circula el agua de la fuente, y con formación de costras de carbonatos cálcicos en zonas adyacentes. La base granítica en que se apoya el carro de la Diosa Cibeles, presenta un mayor deterioro, con un incremento de su porosidad y apreciándose procesos de arenización. Sobre las adamellitas de los vasos de la fuente aparecen también costras carbonáticas. Existe también formación de costras biogénicas.

El agua de la Fuente incrementa su concentración en cloruros, sulfatos y bicarbonatos, así como en calcio y magnesio. Con respecto al agua del Canal.

Para evitar la degradación de los materiales de la Fuente de Cibeles es necesario controlar periódicamente la composición de las aguas que circulan en su circuito cerrado. Según los valores de acidez determinados no sería necesario aplicar al agua ningún correctivo, para tener el agua de la Fuente a un $\mathrm{pH}$ lo más próximo posible a 7,8, barrera geoquímica de la estabilidad para la calcita. Existen en el mercado productos especiales que contienen las dosificaciones específicas para mantener la concentración de cloro, bactericidas y algicidas, estabilidad de la acidez, etc.; lo que facilita el mantenimiento del agua con la correspondiente dosificación. Para un buen mantenimiento se hace necesario poner en uso la depuradora, limpiando todo el circuito del agua, añadiendo a la misma productos desincrustantes y biocidas a base de bifloruro amónico y ácido fluorhídrico, con productos tensoactivos para eliminar óxidos, costras y materia orgánica.

Para mejorar la conservación de la Fuente, y evitar la formación de costras biógenas de sulfatos, es aconsejable limpiar y revisar todo el sistema de iluminación, dejando los focos prácticamente a nivel
Enzymatic biocatalytics of the desmolase variety break up proteids, letting out sulfate ions which cause for an occasional increase in their presence and provoke random calcium sulfate precipitations.

\section{CONCLUSIONS}

The main Fountain's sculptoric group was made of dolomitic marble from Montesclaro's quarries (Toledo, Spain). The cherubs placed in 1864 were sculpted in calcitic marble from Carrara (Italy).

Fountain's basins were made of biotitic adamellite from Valdemorillo's quarries (Madrid, Spain). These Cherubs' calcitic marble present the worst conservation state, with dissolutionbreak-up processes in areas in which the Fountain's water circulates and with calcium carbonates crusts development on adjacent areas. Granitic base, on which the Goddes' chariot leans, shows more important damages, with porosity increase and disgregation processes. There also appears calcitic crusts on the basins' adamellites. And formation of biogenous sulphate crusts.

Fountain's water increases chlorides, sulphates and bicarbonates content, as well as calcium and magnesium concentration

In order to prevent material degradation of the Cibeles Fountain periodic control of the composition of water flowing in its closed circuit is necessary. According to the stated acidity values it would not be necessary to add any treatment on the water in order to keep water $p H$ as close as possible to7.8, the geochemical barrier for calcite stability. There are products in the market with dosage specifications to keep an optimum chloride, bactericide, algaecide and acidity level, etc., this aids water preservation, as does the use of a filter system, that cleanses the whole circuit and adds descaling and biocide products. These products should be ammonium bifluoride and flourhidric acid- based with tensoactive products that can eliminate oxide, crusts and organic matter.

Aiming for a better preservation of the Fountain and preventing the formation of biogenous sulfate crusts, it is advisable to clean and monitor de lighting system, setting appliances at 
del rebosadero y lámparas de luz blanca o azulada de baja longitud de onda. Igualmente, la limpieza del Monumento puede ser realizada con cepillo de raíces y agua jabonosa para posteriormente ser aclarada con chorro de agua a presión y caliente, según ensayos previos realizados (2).

Por último, es conveniente que la Fuente funcione todo el año de día y de noche, no sólo por estética sino para evitar su degradación por efecto de humedad-sequedad o hielo-deshielo.

\section{AGRADECIMIENTOS}

Agradecemos al Ayuntamiento de Madrid (Departamento de Conservación de Edificaciones), las facilidades dadas para la realización del trabajo. brim level and installing short wave white or blue light lamps. Likewise, the cleaning process for the Monument can be carried out using a root brush and soapy water that can be later rinsed with hot water jet at a high pressure, as previously assays recommend (2).

Lastly, it would be advisable to have water flowing in the Fountain day and night, not only for its ornamental effect, but also in order to prevent dryness-wetness or thaw-freeze degradation.

\section{ACKNOWLEDGEMENTS}

We wish to express our gratitude to the Building Preservation Department of Madrid City Council (Ayuntamiento de Madrid, Departamento de Conservación de Edificaciones), for their assistance in carrying out our work.

\section{REFERENCIAS}

(1) R. Mesoneros Romano: El Antiguo Madrid. Facsimil de Agustín Criado. Gráficas Lormo, Madrid, p 399 . 1981

(2) F. Mingarro, M.C. López de Azcona, R. Fort, A. Alonso: Degradación de los materiales pétreos en la Fuente de Cibeles. Informe del Ayuntamiento de Madrid.p 85.1993.

(3) A. Martínez Carbajo, P. Garcia Gutiérrez: Fuentes de Madrid. Editorial El Avapiés S.A., Madrid. p 258. 1994

(4) RILEM: Recommended tests to measure the deterioration of stone and to assess the effectiveness of treatment methods. Commission 25-PEM (Protection et erosion des monuments), Materials and Structures, 75 (1980), pp. 175-253.

(5) ICR-CNR. NORMAL 11/85. 1986. Water absorption by capillarity. Capillarity absorption coefficient. NORMAL 21/85. 1986. Water vapour permeability. ICR-CNR Ed., Roma.

(6) C. Rodríguez-Navarro, E. Sebastián:Técnicas de análisis del sistema poroso de materiales pétreos ornamentales: usos y limitaciones. Ingeniería Civil,96(1994),pp. 130-142.

(7) S. Ordoñez, R. Fort, M.A. García del Cura: Pore size distribution and the durability of a porous limestone. Quartely Journal of Engineering Geology, 30(1997), pp. 221-230.

(8) F. Bellido, C. Casquet, M.J. Huertas, E. Ibarrola, M.T. Ruiz,.: Mapa Geológico de España (2ª Serie), 1:50.000, hoja 533, San Lorenzo de El Escorial, ITGE, Madrid. 1991. 